\title{
Rare case of unilateral optic nerve aplasia
}

\author{
Rashim Mannan, ${ }^{1}$ Parijat Chandra ${ }^{2}$
}

${ }^{1}$ Baba Deep Singh Ji Charitable Hospital, Amritsar, Punjab, India

${ }^{2}$ Dr Rajendra Prasad Centre for Ophthalmic Sciences, All India Institute of Medical Sciences, New Delhi, India

\section{Correspondence to} Dr Parijat Chandra, parijatchandra@gmail.com

Accepted 4 December 2015

\section{DESCRIPTION}

A 2-year-old boy presented with left divergent squint, microphthalmos and microcornea (figure 1). He was born preterm at 32 weeks with birth weight of $1750 \mathrm{~g}$. There was a few days' history of neonatal intensive care unit stay after birth, with no notable systemic complications. Fundus examination using a RetCam revealed an aplastic disc with absence of retina and retinal vasculature, and prominence of choroidal vasculature (figure 2). The right eye was normal.

A paediatric work up revealed no other systemic abnormality. A complete immunoassay by TORCH test revealed raised titres of cytomegalovirus (CMV) $\mathrm{IgG}$ at $145.10 \mathrm{IU} / \mathrm{mL}$ (positive $>30 \mathrm{IU} / \mathrm{mL}$ ), though

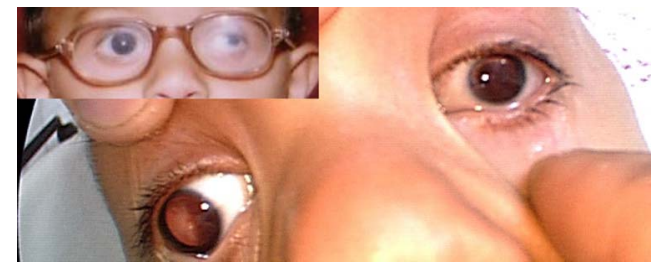

Figure 1 Left divergent squint (inset) with microphthalmos/microcornea of the left eye (larger image).

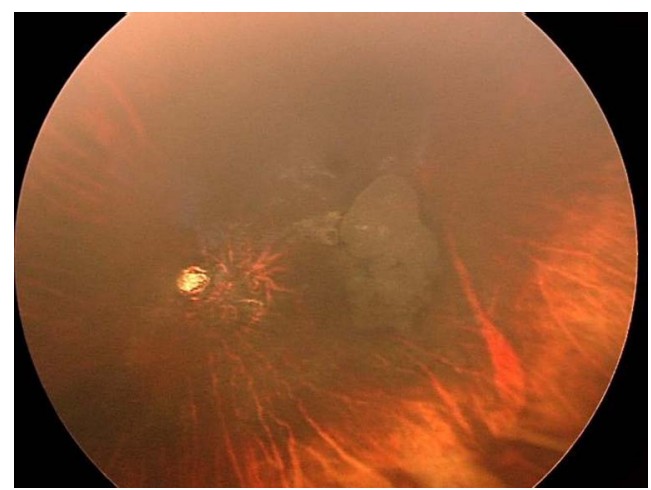

Figure 2 RetCam fundus image of the left eye depicting an aplastic disc with an absent retina and retinal vasculature. Grossly prominent choroidal vasculature is also seen.

the CMV IgM levels were normal and urine PCR for CMV antigen was negative. MRI of the head and orbits revealed that the left optic nerve was not visualised from the back of the eyeball to the optic chiasma, while the right optic nerve was normal in its entire course (figure 3 ). It was explained to the parents that the left eye had no potential for vision.

Optic nerve aplasia is a rare congenital malformation consisting of complete absence of the optic

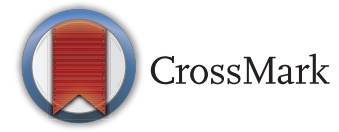

To cite: Mannan $R$ Chandra P. BMJ Case Rep Published online: [please include Day Month Year] doi:10.1136/bcr-2015213510

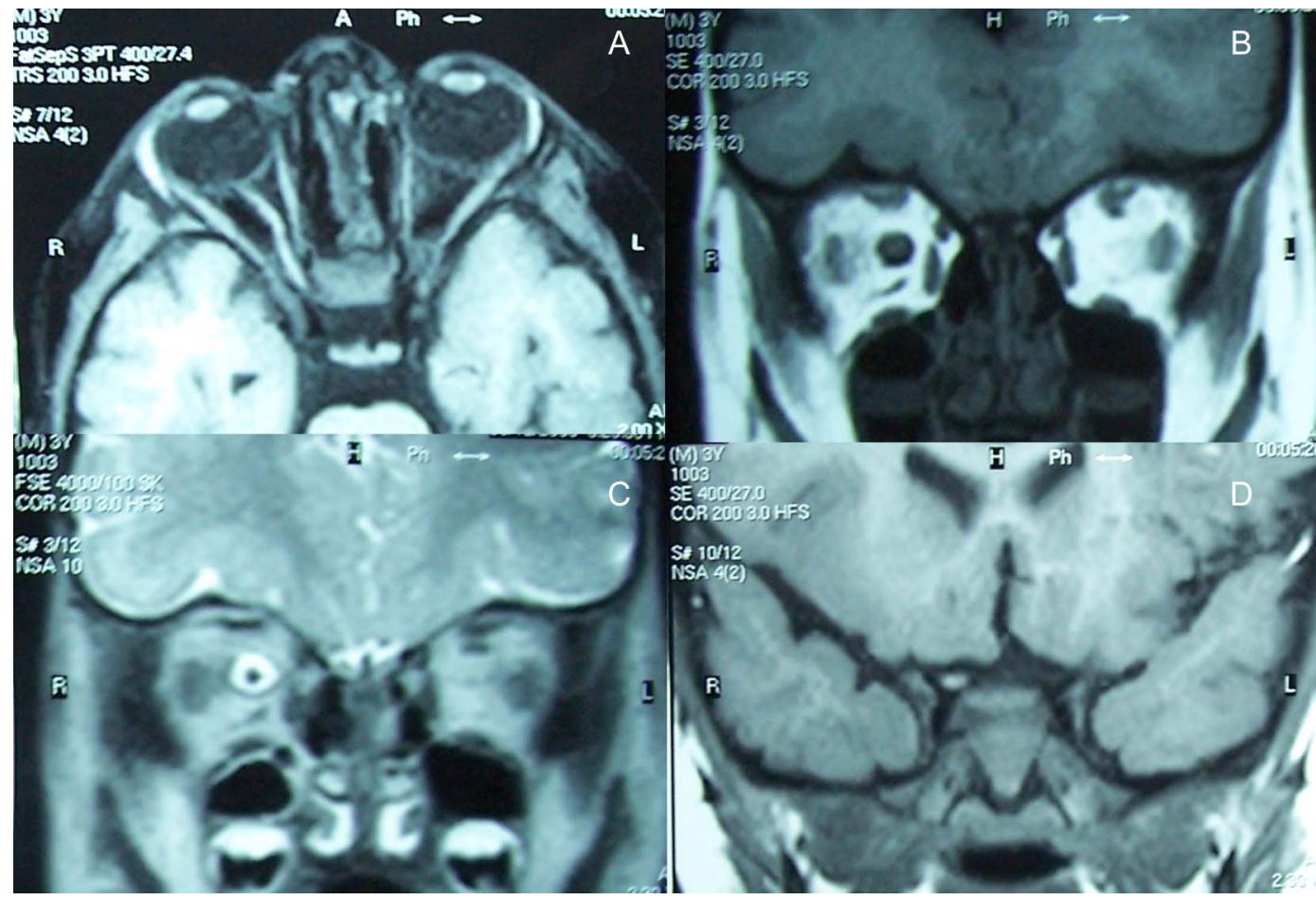

Figure 3 A composite image of sections of MRI of the head and orbit. (A) T1-weighted axial image of the orbit showing absence of the left optic nerve. (B) T2-weighted coronal sections of the orbit showing absence of the intraconal part of the optic nerve. (C) T2-weighted coronal sections of the orbit showing absence of the intracanalicular part of the optic nerve. (D) T2-weighted coronal sections of the intracranial part of the optic nerve near the chiasma, showing absence of optic nerve. 
nerve and its constituents, namely, the optic papilla, retinal ganglion cells and retinal vessels. ${ }^{1}$ The optic nerve arises from a stalk of neural tube cells, but the axons within the nerve arise from the ganglion cells, which are formed within the retina. Thus, the absence of the stalk means that the retinal vessels cannot pass into the eye, so the retina is aplastic, and any ganglion cells that form on the retina have no optic nerve to guide their axons through. So, optic nerve aplasia is an early event in optic stalk formation that prevents further development of the retina and optic nerve in general.

The bilateral form is rarer and may be associated with central nervous system (CNS) anomalies such as hydranencephaly. $^{2}$ A possible association between CMV and optic nerve aplasia could not be demonstrated here because positive IgG findings are common and relatively non-specific. A high index of suspicion for optic nerve aplasia should be kept in all microphthalmic eyes where fundus examination is difficult, and in such cases MRI serves as a useful diagnostic tool to visualise the optic nerve course and detect other CNS anomalies.

\section{Learning points}

- Optic nerve aplasia is a very rare anomaly and should be suspected in all microphthalmic eyes.

- MRI serves as a useful diagnostic tool to confirm diagnosis and rule out other neural anomalies.

Competing interests None declared.

Patient consent Obtained.

Provenance and peer review Not commissioned; externally peer reviewed.

\section{REFERENCES}

1 Ghassemi F, Bazvand F, Hosseini SS, et al. Optic nerve aplasia: case report and literature review. J Ophthalmic Vis Res 2015;10:187-92.

2 Storm RL, Pebenito R. Bilateral optic nerve aplasia associated with hydranencephaly. Ann Ophthalmol 1984;16:988-92.

Copyright 2015 BMJ Publishing Group. All rights reserved. For permission to reuse any of this content visit http://group.bmj.com/group/rights-licensing/permissions.

BMJ Case Report Fellows may re-use this article for personal use and teaching without any further permission.

Become a Fellow of BMJ Case Reports today and you can:

- Submit as many cases as you like

- Enjoy fast sympathetic peer review and rapid publication of accepted articles

- Access all the published articles

- Re-use any of the published material for personal use and teaching without further permission

For information on Institutional Fellowships contact consortiasales@bmjgroup.com

Visit casereports.bmj.com for more articles like this and to become a Fellow 